\title{
Greece: A Procedural Defence of Democracy against the Golden Dawn
}

\author{
Anthoula Malkopoulou*
}

Greece not a militant democracy - Constitution rejects party bans - Challenge posed by neo-Nazi party Golden Dawn - Preference for a procedural approach - Not as passive as previously thought - Proactive use of regular law - Golden Dawn charged for being a criminal organisation disguised as a political party Questions about the political timing of the trial - Importance of judiciary independence - Why not a terrorist organization - Suspension of party funding and other restrictions against Golden Dawn - Actions by state institutions as opposed to local and civil society - How to distinguish between procedural- and militant-democratic initiatives - Political rights of convicted party leaders - Benefits and risks of procedural model

\section{INTRODUCTION}

On 18 September 2013, around midnight, in the Keratsini district of western Piraeus, a large group of men armed with clubs were chasing a smaller group

*Associate Professor, Department of Political Science, Lund University. Research for this paper was conducted in spring 2019 during a visiting fellowship at the Seeger Center for Hellenic Studies, Princeton University, whose funding and support I would like to gratefully acknowledge. Kim Lane Scheppele, Nancy Bermeo, Christopher Achen, Dimitri Gondicas and other participants in a workshop at Princeton (April 2019) provided valuable feedback on earlier drafts, as did Peter Stone and participants at the Higher Research Seminar at Trinity College Dublin (September 2019) and members of the project 'Populism and Democratic Defence in Europe' (September 2020). I would also like to warmly thank Vasiliki Georgiadou, Bastiaan Rijpkema, Sofia Näsström, Tore Olsen, Ben Moffit, Fabio Wolkenstein, Dimitris Christopoulos and especially Angela Bourne for offering advice and critical comments that helped greatly improve the manuscript.

European Constitutional Law Review, 17: 177-201, 2021

(C) The Author(s), 2021. Published by Cambridge University Press on behalf of European Constitutional Law Review. This is an Open Access article, distributed under the terms of the Creative Commons Attribution-NonCommercial-NoDerivatives licence (http://creativecommons.org/licenses/by-nc-nd/4.0/), which permits non-commercial re-use, distribution, and reproduction in any medium, provided the original work is unaltered and is properly cited. The written permission of Cambridge University Press must be obtained for commercial re-use or in order to create a derivative work.

doi:10.1017/S1574019621000146 
of antifascist activists down the road. Minutes later, rap musician Pavlos Fyssas was stabbed to death. The perpetrator, a member of the neo-Nazi party Golden Dawn [Chrysi Avgi], was arrested on the scene. According to the preliminary investigation, he had been ordered there through a command chain involving the party's elected leaders. On the basis of these findings, ten days later, 69 Golden Dawn members, including the leader and all of its 18 MPs, were arrested and jailed. The main charge: directing or having joined a criminal organisation. These events opened the scene for the Golden Dawn trial, 'the biggest trial of fascist criminality since Nuremberg, ${ }^{1}$ which began on 20 April 2015.

Five and a half years later, on 7 October 2020, with thousands of anti-fascist demonstrators gathered outside, a three-member Athens Criminal Court announced its unanimous decision: Golden Dawn was declared a criminal organisation operating 'under the cover' of a political party. By 22 October 2020, the sentences were finalised: seven former MPs and party cadres (including the leader, Michaloliakos) were convicted for leading the organisation and received 10-13 year jail sentences without remand. The remaining 11 former MPs, along with 32 other individuals, were deemed to have joined a criminal organisation and jailed for 5-12 years (and life for the assassin of Fyssas). ${ }^{2}$ The court's decision was hailed by all political parties as a victory against fascism.

It is important to keep in mind that the Golden Dawn trial was a criminal trial, and not a 'political' trial, as it is sometimes mistakenly described in the press. ${ }^{3}$ Prosecuting a political party under criminal law was made possible by the fact that Golden Dawn's gradual electoral success went hand-in-hand with an escalation of politically-motivated criminal activity. Registered as a party since 1983, Golden Dawn had first contested (EU) elections in 1994 (scoring 0.11\%), at the same time as it had started to promote street violence. Following a criminal indictment in 1998 and unfavourable political developments, the party resurfaced only in the late 2000s and elected its first municipal councillor in $2010 .{ }^{4}$ In June 2012, in the first election following the outbreak of Greece's sovereign debt crisis, Golden Dawn made its debut in the Greek parliament, with 18 MPs. Thereafter,

${ }^{1}$ W. Horner, 'What "the biggest trial of fascist criminality since Nuremberg" means for the future of Greece', OpenDemocracy, 17 November 2016.

${ }^{2}$ An additional seven persons received smaller sentences, and 12 more were acquitted. For a detailed list of all sentences, see 〈https://jailgoldendawn.com/wp-content/uploads/2020/10/ПINA $\mathrm{KA} \Sigma$-ПOIN $\Omega \mathrm{N}-1-1 . \mathrm{pdf}$ (in Greek), visited 8 June 2021.

${ }^{3}$ I. Kitsantonis and I. Marga, 'Golden Dawn Found Guilty of Running Criminal Organization in Greece', New York Times, 7 October 2020.

${ }^{4}$ A.A. Ellinas, 'The Rise of Golden Dawn: The New Face of the Far Right in Greece', 18 South European Society and Politics (2013) p. 547-549. 
racist violence in the country greatly increased, ${ }^{5}$ with international organisations and civil society groups repeatedly asking for legal action.

Ever since the pre-trial detention of Golden Dawn leaders in 2013 and until the 2020 verdict, the public debate was captured by the binary dilemma 'political party or criminal organisation?'. Opinions were split about whether Golden Dawn could or should have been banned under Greek law, considering the limits of the existing legal framework, but also the challenges this would have posed to democratic openness and universal political rights. A pluralist democracy, it was thought, could hardly block the road to a popularly elected party, which continued to attract $7-8 \%$ of the vote even after the trial began. ${ }^{6}$ What could be done to respond to such a popular yet violent party in a way that was both legal and legitimate? And what can the Greek case teach us about how anti-democratic parties should be handled in a liberal democratic state?

To answer these questions, we need to understand the peculiarities of the Greek model of democratic defence, its history, rationale, and the way it was put into practice in the Golden Dawn case. To do this, I situate the Greek state's actions against Golden Dawn in an analytical framework that distinguishes between a 'militant' model of democratic defence on one hand, and a 'procedural' model on the other: the former works by proscribing parties that oppose democratic values, while the latter punishes individuals with the use of regular criminal law. ${ }^{7}$ To be sure, this distinction is schematic and in practice the boundaries between the two models are very blurred, as discussed in detail throughout this paper. ${ }^{8}$ Nevertheless, thinking about these two models in ideal-typical terms is not only pedagogically instructive and analytically useful; it also emerges from their

\footnotetext{
${ }^{5}$ A.A. Ellinas, Organizing against Democracy: The Local Organizational Development of Far Right Parties in Greece and Europe (Cambridge University Press 2020) p. 142-146.

${ }^{6}$ For an interpretation of its success on the basis of contextual economic and organisational factors, see A.A. Ellinas, 'Neo-Nazism in an Established Democracy: The Persistence of Golden Dawn in Greece', 20 South European Society and Politics (2015) p. 10.

${ }^{7}$ A. Malkopoulou and L. Norman, 'Three Models of Democratic Self-Defence: Militant Democracy and its Alternatives', 66 Political Studies (2018), pp. 442-458.

${ }^{8}$ In fact, calling the second model 'procedural' may be overlooking the fact that, on one hand, this model is grounded not only on protecting procedures but also on protecting values and, on the other, the militant model also aims to safeguard both values and fair procedures. To avoid this illusive dichotomy, the 'procedural' model could perhaps be renamed as the 'criminal' model. My choice of terminology, however, is based on the distinction between 'procedural democracy' and 'militant democracy' within democratic theory. In this sense, the term 'procedural' is intended to link to the positivistic democratic tradition that underlies this model, one that sees democracy as a system of formal procedures that are equally balanced out. This tradition employs procedural values, that is, values that matter only inasmuch they inform the procedures that uphold them. By contrast, 'militant' stands for a democratic system that is bound to substantive values: these remain over and above procedures and rights and can always be invoked to override them. I thank an anonymous referee for urging me to clarify this point.
} 
contrasting normative bases and discursive justifications. I contend that the Greek case belongs squarely to the latter 'procedural' type. Unlike the militant type, which has attracted the lion's share of scholarly attention in recent years, the procedural approach to democratic self-defence has seldom been discussed in the literature. As such, the Greek case highlights a particular type of response that democratic states can mobilise in their struggle against far-right political parties.

The paper is structured in two main sections that explain, briefly, what each of the two models - militant and procedural - stands for and, in detail, how they manifest themselves in the Greek context. The first section addresses the past, present and future of militant democracy in Greece. It includes a historical explanation of why Greece did not adopt a militant constitution and possible elements of militancy in the current legal framework. The second section focuses on the criminal side of the procedural model, namely how it was applied to build a case against Golden Dawn. The handling of the case is assessed both in connection to the political context and the specifics of the law. The article then discusses other state initiatives that help underline the distinctive characteristics of the procedural model, as well as the issues that emerged after the verdict. It concludes with the lessons that can be drawn from the use of the procedural (and not the militant) model in Greece.

\section{The Militant MODEL}

The most well-known model of democratic defence is usually referred to as 'militant democracy'. Although there is no consensus in the literature on a definition, militant democracy can be described as a normative framework according to which democracies can legitimately restrict the rights and freedoms of those who intend to abolish democracy through nonviolent means. ${ }^{9}$ The most orthodox instruments of militant democracy are party bans and restrictions on the freedom of speech. ${ }^{10}$ Another typical militant democratic tool are eternity clauses, i.e. constitutional provisions such as the right to human dignity or the republican form of government that can be neither repealed nor amended even if such changes fulfil the procedural requirements. ${ }^{11}$ Karl Loewenstein, the first advocate of the concept,

${ }^{9} \mathrm{~K}$. Loewenstein, 'Militant democracy and fundamental rights, I', 31 American Political Science Review (1937) p. 417; J.W. Müller, 'Militant Democracy', in M. Rosenfeld and A. Sajó (eds.), The Oxford Handbook of Comparative Constitutional Law (Oxford University Press 2012) p. 1253.

${ }^{10} \mathrm{~J} . W$. Müller, 'Protecting popular self-government from the people? New normative perspectives on militant democracy', 19 Annual Review of Political Science (2016) p. 249.

${ }^{11}$ Eternity clauses often go hand-in-hand with the possibility of party bans, as argued in R. Weill, 'On the Nexus of Eternity Clauses, Proportional Representation, and Banned Political Parties', 16 Election Law Journal: Rules, Politics, and Policy (2017) p. 237. Yet many countries, including Greece, may have eternity clauses, but reject party bans: M. Hein, The Constitutional Entrenchment Clauses Dataset (University of Göttingen 2018) p. 40, available at 〈http://data.michaelhein.de〉, visited 8 June 2021. 
recommended a longer list of legislative measures, including legislation against party militias and political uniforms, restrictions of parliamentary immunity, freedom of assembly, opinion, speech and press, and the establishment of a political police $^{12}$. Most state legislations nowadays include some of these measures, which can be included in legislation other than constitutional, and in this sense some degree of militancy is globally a commonplace. ${ }^{13}$

In normative terms, 'militant democracy' assumes that a country's fundamental legal instruments include a substantive provision about democracy that serves as a yardstick for judging the legality of political actors. This substantive provision prescribes the democratic credentials that all political parties active in the country's territory must abide to. ${ }^{14}$ In the case of Germany, for example, parties must not 'by reason of their aims or the behaviour of their adherents, seek to undermine or abolish the free democratic basic order or to endanger the existence of the Federal Republic of Germany' (Article 21(2), Grundgesetz, emphasis added). The European Court of Human Rights also approves of such doctrine; in its 2003 decision upholding Turkey's ban of the Islamist Refah Party, it proclaimed that both the ends and the means of a political party must be compatible with the concept of a 'democratic society'. ${ }^{15}$ In both cases, a predefined substantive principle or value associated to democracy is granted superior status and conditions the admissibility of all political actors. Militant democracies require parties to abide to such a normative democratic criterion.

Is Greece a militant democracy? It depends on how broadly we define the term. If we narrow it down so that militant democracy consists of a constitutional or legal provision that permits party bans on the basis of substantive pro-democratic principles, then Greece is not a militant democracy. For historical reasons, the

\footnotetext{
${ }^{12} \mathrm{~K}$. Loewenstein, 'Militant democracy and fundamental rights, II', 31 American Political Science Review (1937) p. 638.

${ }^{13}$ S. Tyulkina, 'Militant democracy as an inherent quality of a democratic state', in A. Malkopoulou and A.S. Kirshner (eds.), Militant Democracy and its Critics: Populism, Parties, Extremism (Edinburgh University Press 2019) p. 207.

${ }^{14}$ Granted, militant democracies often consider as their substantive provision (that warrants rights-restrictions) the religious character of the state, for example Jewishness in the case of Israel, or the state's secular nature, as in Turkey. But these provisions are not directly linked to democracy, and thus using the term militant democracy (instead of, for example, militant constitutionalism) in these cases is a misnomer. I thank Bastiaan Rijpkema for urging me to clarify this point. See also A. Sajó, 'Militant Constitutionalism', in Malkopoulou and Kirshner, supra n. 13, p. 187.

${ }^{15}$ ECtHR 13 February 2003 [GC], Case No. 41340/98, No. 41342/98, No. 41343/98, No. 41344/98, Refah Partisi (The Welfare Party) and others v Turkey. It is worth noting that the ECtHR did not consider the party's non-secular character to be a problem per se; instead, it justified the ban in relation to the party's endorsement of violence and its plans to institute a legal system (sharia) that would create state discrimination against other religious groups and contradict many freedoms guaranteed by the European Convention on Human Rights.
} 
Greek system offers ample protection to political parties. Yet, the rise of Golden Dawn provoked different interpretations of existing laws and a renewed interest in introducing militant democratic provisions. In what follows, the reasons for Greece's aversion towards party bans and the debate about the potentiality or desirability of militant democratic provisions in Greece are presented in detail.

\section{$A$ historical aversion to party bans}

Two main reasons explain why Greece is so unwelcoming of party bans today. The first has to do with the bitter cold war experience of the ban against the Communist Party. Introduced in the aftermath of the Civil War, Law 509/ 1947 ordered the dissolution of every political party, association or organisation that aimed to directly or indirectly act on ideas whose goal was to overthrow through violent means the form of government, the current social system or to remove part of the land's territory'. ${ }^{16}$ On the basis of this law, the Greek Communist Party was continuously banned until $1974 .{ }^{17}$ The second reason that made the Third Greek democracy resistant to party bans is the memory of the military junta's dissolution of all political parties in 1967 (retrospectively legalised by Emergency Law 575, 27 September 1968). In addition, the Colonels' 1968 constitution had established a puppet Constitutional Court, which would be responsible for the 'continuous supervision' of political parties [Article 58(4)] and could outlaw them even if their actions were nonviolent and formally legal, which substantially lowered the threshold for prosecution. Thus, after the military dictatorship's collapse in 1974, laws and practices regarding party dissolution were tainted with the memory of anti-communism and dictatorial oppression in Greece.

Still, party bans were almost introduced in the democratic 1975 Constitution that is in force today. The majority conservative government of the time supported a German-style 'militant democracy', only to be opposed by the centre left. The latter pushed for a 'tolerant democracy', which would be open to radical 'currents' as long as they did not use violent means; in their view, the only real threat was a

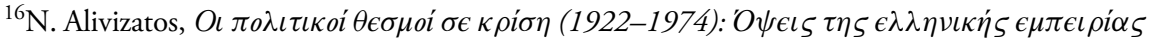
[Political institutions in crisis, 1922-1974: Aspects of the Greek experience] (Themelio 1983) p. 512. All translations from modern Greek into English are my own, unless otherwise indicated.

${ }^{17}$ Some scholars have described this as a 'lapsed ban' because the party was allowed to participate under a different guise, in this case through the United Democratic Left, see A. Bourne, 'Democratization and the illegalization of political parties in Europe', 19 Democratization (2012) p. 1069 at p. 1077. I am sceptical about this interpretation, however, for not only did the ban force the Communist party into unfavourable political concessions, it also legitimised a relentless political prosecution, imprisonment and exile, of many of its members: see Alivizatos, supra n. 16.
} 
return of the far right. ${ }^{18}$ At the end, as a sign of its willingness to achieve a broader consensus, ${ }^{19}$ the conservative majority withdrew its provision for party bans from the 1975 Constitution. Since then, Greece has become so averse to party bans that registering as a party is claimed to be a deliberate strategy of self-protection for parties such as Golden Dawn that would otherwise be operating at the margins of legality. ${ }^{20}$

\section{Novel interpretations}

Within this permissible framework, some conditionality for the recognition of parties still exists. The Constitution's Article 29(1) on political parties stipulates that parties' 'organization and activity shall serve the free functioning of the democratic form of government'. This was to some extent a concession to the rejection of party bans back in 1975, one that acquired new force during the debate about Golden Dawn. Indeed, in recent years a minority of scholars maintained that this constitutional passage can be interpreted as a substantive militant provision. For example, Public Law Professor Charalambos Anthopoulos ${ }^{21}$ argued that Article 29(1) legitimises a court to order a party ban; in fact, it could serve as the ground for a much-needed new law that would implement this constitutional provision, one that would enable the Supreme Court to order party bans after a case is brought in by the Minister of Justice or the Parliament. Yet, this interpretation of Article 29(1) was almost unanimously rejected by most Greek constitutional scholars. $^{22}$

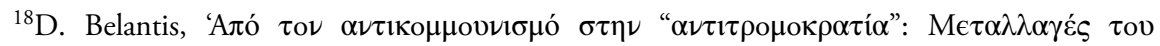

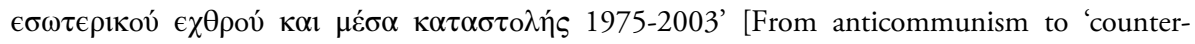
terrorism': Transformations of the internal enemy and means of repression 1975-2003], in

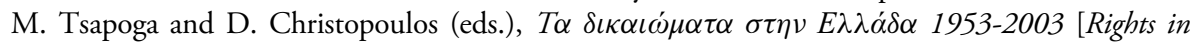
Greece 1953-2003] (Kastaniotis/Hellenic League for Human Rights 2004) p. 372.

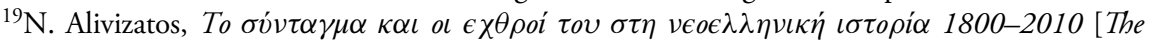
Constitution and its enemies in modern Greek history 1800-2010] (Polis 2011) p. 500.

${ }^{20}$ D. Psarras, Golden Dawn on Trial (Rosa Luxemburg Stiftung 2015) 〈https://rosalux.gr/sites/ default/files/publications/gd_on_trial_web.pdf), visited 8 June 2021.

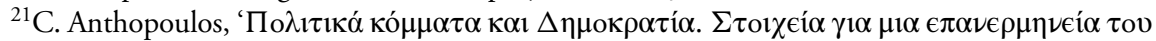
$\alpha ́ \rho \theta \rho o v ~ 29 \pi \alpha \rho .1 \Sigma v \nu \tau$.' [Political parties and Democracy. Grounds for a reinterpretation of Article 29, para. 1 Const.], $2 \epsilon \varphi \eta \mu \Delta \Delta$ (2015) p. 157.

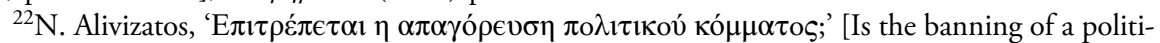

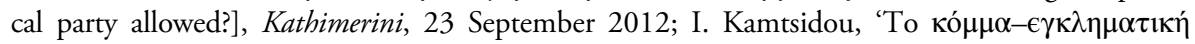

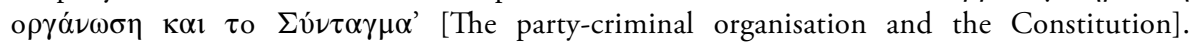
Constitutionalism.gr, 18 October 2013, 〈www.constitutionalism.gr/komma-egklimatiki-

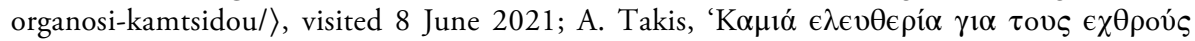

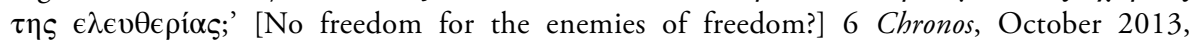
〈www.chronosmag.eu/index.php/index.php/s-lth-g-th-lth.html〉, visited 8 June 2021. 
Whereas this constitutional description of the role of parties is not viewed as a pre-condition for recognising a political party, Greek electoral law does include one provision that has a distinct militant character. Article $27(6)$ of the Election Law (4735/2020), which was introduced in $1984,{ }^{23}$ prohibits the use as a name, emblem or sign of a party of (1) religious symbols, the national flag or similar insignia, (2) the crown and (3) symbols or emblems of the 21 April 1967 dictatorship or photographs of persons who have been convicted for their participation therein. This law has been put to use only once, in 2007, when the Supreme Court (Decision 4/2007) rejected a party named 'New Fascism' (Neos Fasismos) and admitted its single candidate as a party-less candidate. ${ }^{24}$ The practice of disallowing the reuse of the 1967 dictatorship symbols falls squarely within the logic of 'negative republicanism', as described by Peter Niesen. Negative republicanism holds that a democracy can reliably determine its enemy only by looking into the past, that is, in connection to lived experiences that are known to be detrimental to the democratic experiment; thereby it avoids the immense political and democratic risks of having to identify future enemies. ${ }^{25}$ Article 27(6) basically recognises that the Colonel's dictatorship was an enemy of democracy (and implies the same about the crown) and is therefore banned from claiming political power again. For some, Golden Dawn had to be prohibited by mere reference to this law. Drawing on a UN Committee on the Elimination of Racial Discrimination report showcasing the use of neo-Nazi symbols by the party ${ }^{26}$ and its recommendation in favour of banning neo-Nazi organisations in Greece, ${ }^{27}$ a court case was filed by the NGO Greek Helsinki Monitor, yet without success. ${ }^{28}$ Thus, this law has had limited force in halting the rise of Golden Dawn.

\footnotetext{
${ }^{23}$ This paragraph, introduced with Law 1443/1984, was included within Art. 37 in all Election Laws from 1985 until 4648/2019, when it became Art. 27. For an online archive of all election laws in Greece from 1974 until 2007 see 〈www.electoralsystemchanges.eu〉; from 1985 onwards see 〈www.e-nomothesia.gr/kat-bouli-bouleutes/ekloges/〉, both visited 8 June 2021.

${ }^{24}$ Interestingly, for its decision against 'New Fascism' the Supreme Court drew also on the aforementioned Art. 29(1) of the Constitution, which describes the role of political parties.

${ }^{25}$ P. Niesen, Anti-Extremism, Negative Republicanism, Civic Society: Three Paradigms for Banning Political Parties', 3 German Law Journal (2002) p. 1.

${ }^{26}$ Greek Helsinki Monitor, Parallel Summary Report on Greece's Compliance with the International Convention on the Elimination of All Forms of Racial Discrimination, April 2009. 〈https://tbinternet. ohchr.org/Treaties/CERD/Shared\%20Documents/GRC/INT_CERD_NGO_GRC_75_8947_E. doc), visited 8 June 2021.

${ }^{27}$ Committee on the Elimination of Racial Discrimination (2009), Consideration of reports submitted by states parties under article 9 of the Convention: Greece. CERD/C/GRC/CO/16-19, 14 September 2009, 〈http://goo.gl/Lk3jIq , visited 8 June 2021.

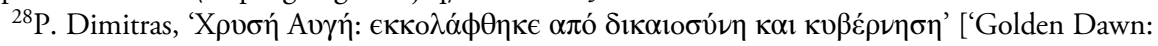
hatched by the justice and government system'], 24 Books Journal, October 2012.
} 
Besides these two provisions - Constitution Article 29(1) and Election Law Article 27(6) - Anthopoulos argued for a third possibility for banning Golden Dawn: the Supreme Court, he wrote, can prohibit Golden Dawn from participating in elections by claiming that the party lied in its founding declaration. ${ }^{29}$ According to Party Law 3023/2002, Article 29(1), when commencing any activity (such as participation in an election) a party is among other things required to submit a founding declaration, where it states that the party's organisation and activity serve the free functioning of the democratic form of government. ${ }^{30}$ This provision replaced an older one that required parties to declare their principled opposition to the violent takeover of power or overthrow of free democratic government (often referred to as 'declaration of conformity to law' [délosé nomimofrosyness]) (Law 59/1974, Article 1[2]), which was in place for 28 years until 2002. In fact, drawing on the 1974 law, in 1994 the Supreme Court denied electoral participation to three parties for not having submitted said declaration (Decision 869/1994). That decision was heavily criticised at the time and led to a revised decision (903/1994) allowing the three parties to retroactively submit their declarations. ${ }^{31}$ On these grounds, most legal scholars disagreed with Anthopoulos' suggestion; they claimed that the declaration mentioned in the newer 2002 law is merely formal since no background check by the Court is foreseen. ${ }^{32}$

Still, some have insisted that it would be at least constitutional to re-introduce the 1974 law to tackle Golden Dawn, adding a third point to the required declaration besides opposition to a violent takeover and the overthrow of democracy: that the party leadership has not been convicted in the past for joining a criminal organisation. In this sense, parties should be required to submit a 'declaration of democratic reliability', ironically mirroring the notorious Cold War anti-communist 'declaration of social reliability' [pistopoiētiko koinonnikōn fronēmatōn]. ${ }^{33}$ This strategy goes halfway towards the paradigm of full militant democracy: it requires commitment to substantive democratic principles, but poses limits only and

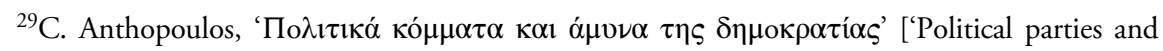
democratic defence'], Kathimerini, 3 July 2016.

${ }^{30}$ This was the Party Law that lifted the Communist Party ban in 1974.

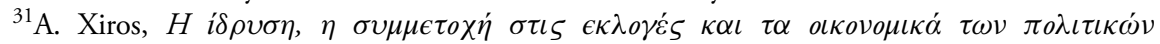

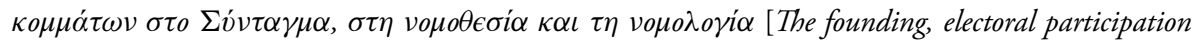
and finances of political parties in the Constitution, legislation and jurisprudence] (Sakkoulas 2014) p. $97-110$.

${ }^{32}$ I thank Angela Bourne for drawing my attention to the similarities between this case and the first - failed - attempt to ban Herri Batasuna in Spain in the 1980s.

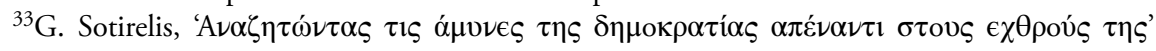
[Searching for democracy's defences against its enemies], Constitutionalism.gr, 14 October 2013. 
specifically for participation in elections, rather than on the formation of parties as such. In this sense, it resembles the Israeli model of militancy, where courts can block the electoral presence of parties without dismantling them. ${ }^{34}$ The same strategy has been included in a constitutional proposal by a group of six public intellectuals. Article 29, they claim, should be revised to enable blocking the election participation of parties (or individuals) whose leadership 'systematically encourages or tolerates the use of violence'. ${ }^{35}$ Whether on grounds of violence or 'democratic reliability', these proposals apply militancy only on power-seeking activities: they reject party bans as such, but do block their participation in elections, one contest at a time.

To conclude, support for militancy and party bans in Greece has moved from complete rejection to reluctant acceptance. The existing legal framework mirrors a reaction to developments prior to 1975 , when party bans were used to squash political dissent and have therefore provoked a 'legal allergy' among Greek lawmakers against them. ${ }^{36}$ Golden Dawn seems to have made clever use of this laissez-faire attitude towards political parties ${ }^{37}$ : it registered as a party as early as 1983 without launching any electoral activity until the 1990s, a sign that their electoral registration was a strategic move in order to receive constitutional protection. ${ }^{38}$ The tide has turned, and now many in Greece and abroad are favourable to some limited type of principled restrictions against 'dangerous' parties. Although such provisions could indeed have a moderating effect, they are increasingly under attack. In the latest case that received international attention, Karlsruhe judges refrained from admitting a party ban against the NPD, ${ }^{39}$ which signals a renewed awareness of the risks that such bans entail in terms of public perceptions of democratic legitimacy. Likewise, changing the permissive legal framework that is in place in Greece would sacrifice the positive consequences that this framework has generated over the past 30 years: a pluralist party culture that encourages political dissent.

\footnotetext{
${ }^{34}$ S. Issacharoff, 'Fragile Democracies', 120 Harvard Law Review (2007) p. 1405.

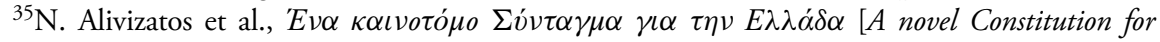
Greece] (Metaichmio 2016) p. 30, 107, 109. See also Kathimerini tis Kyriakis, 5 June 2016.

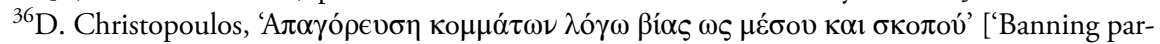
ties due to violence as means and end'], Kathimerini, 3 July 2016.

${ }^{37}$ Anthopoulos, supra n. 29.

${ }^{38}$ Psarras supra n. 20 , p. 55-56.

${ }^{39}$ G. Molier and B. Rijpkema, 'Germany's New Militant Democracy Regime: National Democratic Party II and the German Federal Constitutional Court's "Potentiality" Criterion for Party Bans: Bundesverfassungsgericht, Judgment of 17 January 2017, 2 BvB 1/13, National Democratic Party II', 14 EuConst (2018) p. 394.
} 


\section{THE PROCEDURAL MODEL}

Because of the overwhelming rejection of militant provisions in the Greek legal system, it can be said with certainty that Greece belongs to the alternative, nonmilitant, procedural model of democratic defence. Built on the ideas of Hans Kelsen, the procedural model rejects substantive moral values and supports instead clearly established, value-neutral, legal procedures that promote negative freedom. Substantive constitutional principles, Kelsen explains, stem from value absolutism, which is the bastion of authoritarianism. ${ }^{40}$ Party bans - relying on such substantive principles - are both illiberal and undemocratic; illiberal because they threaten the traction of negative freedom, and undemocratic because they seek to ascertain democracy against the will of the majority. ${ }^{41}$ Thus, democracies can only be maximally inclusive, allowing participation even to those parties that promote unacceptable, even antidemocratic, views.

This view rests on an understanding of democracy as a system where 'many group interests organised into parties compete with one another as such and reach an equilibrium. ${ }^{42}$ This understanding has inspired even minimalist theories that define democracy as a method for regulating competition among competent political elites. ${ }^{43}$ Yet, procedural democracy cannot be reduced to such a view; it defines democracy more broadly as the political process that it puts in motion, ${ }^{44}$ a process of self-governance premised on the equal consideration of the interest of all. ${ }^{45}$ Because equal liberty is so fundamental for procedural democracy, any system of guardianship that allows for formally unequal access to power (e.g. by excluding or obstructing participation for some parts of the population) is to be rejected a priori. Instead, to merit the label 'democracy', a state must strive to grant equal voice and influence in government to all (sufficiently qualified adult) individuals and, by consequence, to all political parties. How then do pure procedural democracies prevent an anti-democratic majority from causing the erosion, decay or collapse of democracy itself?

\footnotetext{
${ }^{40} \mathrm{H}$. Kelsen, The Essence and Value of Democracy (Rowman \& Littlefield 2013 [1929]) p. 103.

${ }^{41}$ H. Kelsen, Verteidigung der Demokratie: Abhandlungen zur Demokratietheorie (Mohr-Siebeck 2006 [1932]).

${ }^{42}$ Kelsen, supra n. 40, p. 73.

${ }^{43}$ J. Schumpeter, Capitalism, Socialism and Democracy (Harper \& Row 1942). Procedural democracy has long been wrongly associated with these minimalist or Schumpeterian theories of democracy: see J. Habermas, Between Facts and Norms: Contributions to a Discourse Theory of Law and Democracy, trans. W. Rehg (MIT Press 1996) p. 332-33.

${ }^{44}$ M.P. Saffon and N. Urbinati, 'Procedural Democracy, the Bulwark of Equal Liberty', 41 Political Theory (2013) p. 441.

${ }^{45}$ R.A. Dahl, Toward Democracy - a Journey: Reflections, 1940-1997. Vol. 2 (Institute of Governmental Studies Press 1997) p. 207-209.
} 
To thwart the danger of democide, procedural models rely, on one hand, on institutional checks and balances and, on the other, on monitoring and sanctioning possible criminal acts of leaders and members of antidemocratic parties. Typically, countries in the common law tradition belong to the procedural model. For example, in the US institutional checks involve presidentialism combined with a majoritarian electoral system that makes it harder for radical minorities to access decision-making; a clear division of power among executive, legislative and judicial authorities, which control each other (e.g. through judicial review of laws and decisions by the Supreme Court); and a federal system that prevents the concentration of power. ${ }^{46}$ At the same time, legal action against parties is permitted only inasmuch they pose an 'imminent danger of direct harm' against other groups or individuals; hence, free speech and free assembly enjoy strong protection and can only be restricted if they incite criminal conduct as stipulated by ordinary criminal law. ${ }^{47}$ This necessarily involves the identification of guilty acts committed by individuals who are therefore deemed punishable. To sum up, the procedural model does not exclude political actors from public life, but makes it hard for marginal forces to access or concentrate power and punishes criminal acts (not speech) by individual politicians.

Despite this principled distinction of the procedural from the militant-democratic model, legal practices are often more mixed. The Spanish case is a good example. There, the possibility to ban political parties is framed in a way that combines a substantial definition of democracy with a list of criminal activities, such as attacks on life and dignity, exclusion of others on racist grounds, enabling violence and supporting terrorist activity (2002 Ley de Partidos Políticos, Article 9[2]). All these acts (including speech-acts) are said to 'violate democratic principles'. Despite attention to activity and specific grave crimes, the restrictions on free speech, the broad scope of this article - that may, for example, prohibit expressing sympathy for a foreign political movement that is fighting a dictatorial regime ${ }^{48}-$ and, above all, the use of democratic principles as the key justificatory mechanism, classifies this law as militant-democratic. Thus, although distinctions are not always easy to make, compared to Spain, Greece falls much more squarely within the procedural paradigm.

The type of institutional checks and balances described above do not exist in Greece. The country does not have a federal system, nor does it have a presidential or a majoritarian election system (and at 3\% not even a high electoral threshold).

\footnotetext{
${ }^{46}$ For a more detailed description of the current strengths and weakness of the American system, see T. Ginsburg and A.Z. Huq, How to Save a Constitutional Democracy (University of Chicago Press 2018).

${ }^{47}$ Issacharoff, supra n. 34, p. 1416.

${ }^{48}$ S. Tyulkina, Militant Democracy: Undemocratic Political Parties and Beyond (Routledge 2015) p. 132-133.
} 
Division of power is also not clear-cut, although the judiciary is in principle independent and depoliticised. Hence, aside from judicial review, which was not relevant in the case of Golden Dawn since the party never came close to law-making, the only other procedural instrument that the Greek state had at its disposal to block a 'dangerous' political actor was the use of criminal law.

\section{Criminal charges against Golden Dawn}

Criminal law was indeed put in motion in the case of Golden Dawn. Three days after the murder or Fyssas in Keratsini, a preliminary investigation was ordered leading to the arrest and pre-trial detention of all 18 Golden Dawn MPs, and 51 other members. Official charges were filed 16 months later (5 February 2015), following a nine-month investigation, a recommendation by the Public Prosecutor and the irrevocable decision of the Judicial Council: Golden Dawn leaders and members were to stand trial for violating Article 187 of the Criminal Code on Criminal Organization. At the same time, following a civil suit by a group of antifascist lawyers, the court was going to try them for three separate felonies: the murder of Fyssas (September 2012), the attempted murder of Egyptian fisherman Abuzid (June 2012) and the attempted murder of a group of trade unionists (September 2012). ${ }^{49}$

The main charge - of setting up a criminal organisation - was based on the association of the defendants with dozens of crimes detailed in the Judicial Council's 1109-page report. It established an overlap between the political structure of the party and its operational branch responsible for organising and executing crimes. In the indictment, it was argued that Golden Dawn is 'an active Nazi-type criminal organization' that uses the status of political party as a cover; it operates with military structure, hierarchy and branches in the whole country, led by Nikos Michaloliakos on the model of the Nazi Führerprinzip and based on a strict chain of command involving MPs and leaders of the party's local offices. ${ }^{50}$ It took the form of criminal organisation in 2008, with a peak of activities in 2012. The decree follows recommendations included in the report of the public prosecutor, where the party's criminal activity is described as directed against foreigners, political dissenters and ideological opponents, aimed at imposing its political ideas through violence, and executed through specially trained

\footnotetext{
${ }^{49}$ The full text of the civil suit against the Golden Dawn is available at $\langle$ https://goo.gl/biwWzg $\rangle$. For how the anti-fascist movement organised itself behind the civil suit, see L. Fekete, 'Lessons from the fight against Golden Dawn', 61 Race \& Class (2020) p. 50.

${ }^{50}$ Judicial Council of the Court of Appeal (2015), Decree 215/2015, p. 47-51.
} 
'battalion troops' or 'hit squads' [tagmata efodou] ${ }^{51}$ In other words, a criminal indictment became possible by arguing that the criminal and political branch of the party were merged.

In this sense, the case against Golden Dawn has distinct characteristics compared to other European examples. For example, in Germany there had been a clear division of labour between party and criminal group and thus separate trials: a criminal trial for far-right terrorist group NSU (2013) and a constitutional trial for far-right party NPD (2003 and 2017). Cases similar to the Greek one, where criminal and political activity in a single organisation overlap, have existed in the past in connection to separatist parties, such as Herri Batasuna in Spain, banned in 2003 on charges of being a front organisation for the Basque terrorist group ETA. Likewise, Sinn Féin in Ireland is often accused (especially in 2005) of collusion with the IRA. By comparison, Golden Dawn was accused not of complicity with a criminal group, but of being such a group itself. Hence, the Golden Dawn trial, which commenced on 20 April 2015 and ended on 22 October 2020,52 produced the first ever conviction of a political party for being an undercover criminal organisation.

\section{The politics of the trial}

However, a number of criticisms regarding the trial are worth highlighting. The most important critique regards the procedure by which the party's prosecution was initiated. One day after the murder of Fyssas and two days before the launch of preliminary investigations, a note was sent to the Prosecutor's office by the Minister of Public Order Nikos Dendias. In that note, the Minister asked the Public Prosecutor to investigate Golden Dawn for acting as a criminal organisation on the basis of a list of 32 cases annexed to the message. ${ }^{53}$

What explains this 'unprecedented' move by the Minister? Here are two possible explanations. First, the Minister acted as if Greece was a German-style militant democracy, where the executive and legislative branch initiates procedures for a party ban by contacting the Constitutional Court. But Greece does not have such a system in place, and the Public Prosecutor should have acted on their own. However - and this is the second explanation - the move was called for because of the judiciary's reluctance to prosecute Golden Dawn despite its

${ }^{51}$ Judicial Council, supra n. 50, p. 50; Public Prosecutor's Office, Report to the Judicial Council of the Court of Appeal, 15 October 2014, p. 27, 〈www.jailgoldendawn.com/wp-content/uploads/ 2014/10/protash_ntogiakou.pdf), visited 8 June 2021.

${ }^{52}$ Its day-to-day proceedings have been published online at $\langle$ https://jailgoldendawn.com/\%CE\% B7-0CE\%B4\%CE\%AF\%CE\%BA\%CE\%B7/〉 and 〈https://goldendawnwatch.org .

${ }^{53}$ See 〈www.jailgoldendawn.com/wp-content/uploads/2013/11/peristatika_xa.pdf), visited 8 June 2021. 
implication in numerous crimes, precisely because it was a political party. For some, this long delay in initiating prosecution was a sign that the judiciary or the government for that matter - had thus far actively protected Golden Dawn out of ideological sympathy. ${ }^{54}$ It is as likely, however, that the judiciary's inactivity was due to compliance with the separation of powers and the ensuing principle of non-interference with the autonomy of the legislative branch; prosecuting a legislative group that enjoyed popular (aka electoral) legitimacy on the grounds of its group activity was a puzzle for the judiciary, whose esprit des corps demanded a double devotion to the party-protecting constitution and to criminal law. Since the two laws were in conflict on that issue, an act of support from the executive branch worked as a green light for the Greek prosecutors that Golden Dawn's prosecution would not be interpreted as undue political interference by Supreme Court judges.

This reluctance of the Prosecutor to act against a political party is the most fundamental weakness of the procedural model. It presupposes not only a strong independence of the judicial branch of power, but also a relationship of trust with the other two branches of government that prevents suspicions of judicial interference. It also requires strong social legitimacy for the courts, to justify their power to move against a popularly elected party or government. Pressing criminal charges against an entire parliamentary group is a controversial task, for which the law must provide a clearer roadmap.

Because of its dubious legal status, the initiative of Minister Dendias was interpreted as a political act par excellence. The government, it was argued, decided to nudge judicial authorities only when it noticed a rising electoral threat from the far-right party. ${ }^{55}$ Polls indeed indicated a rise in support for Golden Dawn from $7 \%$ in May 2012 to $13 \%$ in September $2013,{ }^{56}$ drawing primarily from the governing party's own pool of voters: this established a clear political motive for the government to strike down a menacing rival. The government's political motive was also confirmed in a leaked video, where a high-ranking PM aide is seen to secretly confess that the PM acted because of Golden Dawn's rising support in the opinion polls. ${ }^{57}$ The same video suggests that the government used its sway over judicial authorities to initiate the far-right party's prosecution, casting further doubt over the capacity of the Greek judiciary to act independently against political parties.

\footnotetext{
${ }^{54}$ Psarras, supra n. 20.

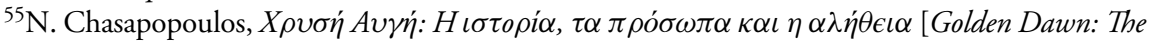
history, the faces and the truth] (Livanis 2013) p. 131-134.

${ }^{56}$ Both polls are available in English at (www.publicissue.gr/en/1818/varometro-sep-2013/〉; 〈www.publicissue.gr/en/1794/varometro-june-2013/〉, both visited 8 June 2021.

${ }^{57} \mathrm{H}$. Smith, 'Greek prime minister facing resignation calls after aide's Golden Dawn gaffe', The Guardian, 3 April 2014.
} 
Allegations about the timing of the prosecution also added to the critique of the government's involvement in sending Golden Dawn to trial. Why was the crackdown initiated in late September 2013? The timing has been usually explained in connection to the criminal act itself, the murder of Fyssas, which provided clear evidence of the party leadership's liability for the members' criminal activity. Yet, several other earlier occasions could have triggered the party's prosecution on criminal grounds. According to Psarras, a 1998 incident of attempted murder briefly discussed in parliament (the so-called Periandros case), which had led to an irrevocable conviction in 2009, was sufficient proof of the party's criminal activity: the Supreme Court had admitted then that the party's attacks were organised, had homicidal intentions and were driven by their ideology. ${ }^{58}$ Likewise, the state could have acted in 2009 on the recommendation by the UN Committee on the Elimination of Racial Discrimination to stop the proliferation of racist attacks by banning associations responsible for them. ${ }^{59}$ Moreover, the murder of a young Pakistani immigrant, Shehzad Luqman, in January 2013 had provided a similar opportunity to take the party to court. ${ }^{60}$ The argument regarding the late timing of Golden Dawn's prosecution is usually intertwined with allegations that the government initiated the prosecution for maximal political gain.

Regardless of whether this charge is well-founded, the problem from a democratic defence viewpoint is how, in more abstract terms, the procedural act of prosecution falls between the cracks of separated powers. In this respect, the Greek case highlights a legal-political paradox inherent in the procedural model of democratic defence. On one hand, it requires an independent judiciary, which can initiate a criminal prosecution against the leaders of a political party. This is a sensitive affair even when it regards prosecution of a party only for financial irregularities or political corruption. Judicial independence is undermined not only when judges are formally appointed by executives or parliaments; it is especially vulnerable when anti-democratic parties ascend to power and deliberately interfere with the composition of courts through court-packing (as has happened recently in Hungary and Poland). On the other hand, public prosecutors should not be emboldened to go after political parties, precisely because this calls into question the judiciary's political neutrality. In other words, the independence of the judiciary is fundamental, not only because prosecutors will otherwise fail to prosecute criminal acts associated with parties, but also because antidemocratic parties may use courts to eliminate their political opponents.

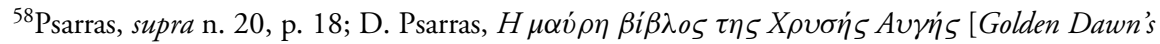
black Bible] (Polis 2012) p. 447-448.

${ }^{59}$ Psarras, supra n. 20, p. 14.

${ }^{60} \mathrm{Y}$. Behrakis and R. Maltezou, 'Anti-racism protesters rally in Athens after stabbing', Reuters, 19 January 2013.
} 
To be sure, militant democracies share this vulnerability. Yet, they overcome it through the direct involvement of executive or legislative authorities in party bans (which, however, makes these bans more susceptible to political manipulation) or through the use of eternity clauses, which are unjustifiable from a procedural democracy viewpoint. By contrast, in procedural democracies, since judiciary authorities alone handle cases of penal law, their independence is a sine qua non of their ability to defend democracy. Seen from this perspective, the conviction of Golden Dawn leaders and members on criminal grounds can be regarded, optimistically, as proof of the Greek judiciary's independence.

\section{Criminal or terrorist organisation?}

Besides the politics surrounding Golden Dawn's trial, it is worth examining some issues that are internal to the legal case against Golden Dawn. As mentioned, the backbone of the legal charge against Golden Dawn was Article 187 of the Penal Code on Criminal Organization. ${ }^{61}$ This article requires up to 10 years' imprisonment for 'any person who sets up or is included as member in a structured group with continuous activity, made up of three or more persons (organisation) that pursues the commitment of more than one felonies', which are listed in this law. It also requires at least 10 years' imprisonment for those who direct such a group. Because directing a criminal organisation fell within the category of 'continuous crime', which allows an arrest any time in flagrante delicto, Golden Dawn MPs could be preliminarily detained without a prior lifting of their parliamentary immunity (which was one of the early points of critique). This was done later in the judicial process, with votes in parliament usually gathering unanimous support.

A second, more important critique regards the legal definition of a 'criminal organisation'. In the respective international treaty (the 2000 'Palermo' Convention), a criminal organisation is defined by having a direct or indirect financial motive. ${ }^{62}$ Hence, according to a minority judge, Golden Dawn could not be accused of being a criminal organisation unless it could be proved that the purpose of its organised criminal activities was material benefit. What the minority judge was implicitly pointing at was the need to focus on the political, rather than generic, nature of Golden Dawn's crimes, which would merit invoking the law against terrorist acts rather than organised crime.

\footnotetext{
${ }^{61} \mathrm{See}\langle$ https://www.lawspot.gr/nomikes-plirofories/nomothesia/pk/arthro-187-poinikos-kodikasegklimatiki-organosi $\rangle$. For English, see $\langle$ https://sherloc.unodc.org/cld/uploads/res/document/grc/ penal_code_excerpts_html/Greece_Criminal_Code_Excerpts.pdf) (p. 28), visited 8 June 2021.

${ }^{62} \mathrm{UN}$ Convention against Transnational Organized Crime, Art. 2(a): “'Organized criminal group" shall mean a structured group [...] committing one or more serious crimes [...] in order to obtain, directly or indirectly, a financial or other material benefit' (emphasis added).
} 
Why did the prosecution not apply Article 187A on terrorist acts? Instead, through Article 187 on criminal organisation they charged the party for being involved in crimes, such as homicide, attempted homicide and grave bodily injury, regardless of the motive or scope of these crimes. The problem here is indeed that the political nature of the crimes, the fact that they did not aim at simple injury but at sending a symbolic political message is hardly acknowledged by this charge. By contrast, Article 187A would be more relevant, as it concerns crimes that may inflict serious harm on a country $[\ldots]$ and aim at seriously intimidating a population $[\ldots]$ or at seriously harming or destroying the fundamental constitutional, political, financial structures of a country or international organization. ${ }^{63}$

As argued by one of the plaintiffs, the party's tactics had a clear aim of intimidating a whole population of immigrants in various suburbs of Athens, who as a result were afraid of leaving their homes at night. ${ }^{64}$ Others, especially from the centre-left, claimed that the party's intimidation campaign extended to more groups, such as antifascists, who were targeted for their beliefs. ${ }^{65}$ This complaint was usually accompanied by remarks on how differently the case would have been handled had this been an anarchist-left organisation. ${ }^{66}$ The so-called 'terror-laws', which involve much harsher penalties, were assumedly designed with such anarchist-left organisations in mind. ${ }^{67}$ This is why radical left supporters often oppose the legitimacy of anti-terror laws altogether, and why they avoid invoking them in the case of Golden Dawn too. Yet, if one puts aside the internal critique of antiterror laws, Golden Dawn's resemblance to a terrorist organisation that falls under Article $187 \mathrm{~A}$ is difficult to deny. From a penal law perspective, it might have been harder to establish the 'terrorist' aspect of Golden Dawn as opposed to its involvement in 'organised crime'. Still, it doesn't suffice to admit that this is organised crime; one needs to legally confront the political nature of these crimes.

\footnotetext{
${ }^{63}$ See /www.lawspot.gr/nomikes-plirofories/nomothesia/pk/arthro-187a-poinikos-kodikastromokratikes-praxeis $\rangle$, visited 8 June 2021.

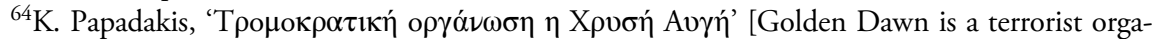
nisation], Interview, Athens Voice, 22 April 2015. Papadakis was a key lawyer for the victims in the Golden Dawn trial.

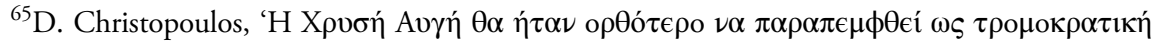

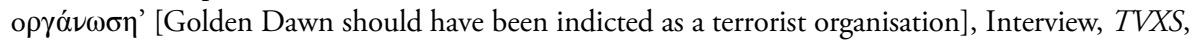

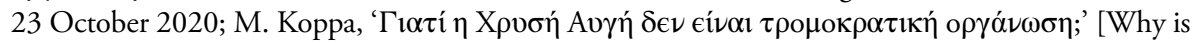
Golden Dawn not a terrorist organisation?], TVXS, 12 October 2013.

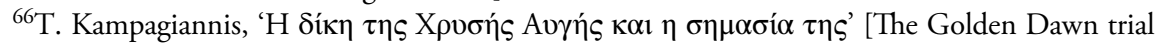
and its significance], Interview, The Cricket, 3 November 2014, 〈http://thecricket.gr/2014/11/ kampagiannis_goldendawntrial//, visited 8 June 2021. Kampagiannis was a key lawyer for the victims in the Golden Dawn trial.

${ }^{67}$ Belantis, supra n.18.
} 


\section{Procedural versus militant restrictions on Golden Dawn}

Some would argue that having anti-terror laws in place and using them to go after political parties qualifies a democracy as militant. I disagree; there is a clear line of separation between militant-democratic and anti-terror laws. In the militant model the illegality of an actor is justified in connection to a principled conception of democracy, defined vaguely for example in the German Basic Law as 'the free democratic basic order'. It is not defined in relation to concrete harm inflicted upon others (e.g. through terrorist violence). As a result, the intervention logic of militant-democratic measures is to impose rights restrictions (e.g. limitations on free speech) for the purpose of defending democratic or related principles. This involves evaluating the ideological content of the views that actors may hold and deeming it impermissible where it undermines an institutionalised political morality. By contrast, anti-terror laws concern cases of serious intimidation of a population or serious harm of a country's fundamental structures (not democratic structures per se).

Likewise, procedural democracies can also introduce anti-racist laws. Anti-racist laws are procedural, not militant, insofar as: (a) they do not prohibit racist ideology, i.e. racist beliefs and ideas per se; and (b) they do not prohibit such ideology because it contradicts liberal, republican or democratic principles. What such laws do is to punish the use of racist ideas with the purpose of inflicting harm on other individuals. In other words, it is the performativity and intentionality of racist discourse, not its content, that procedural democracies criminalise. Moreover, criminalisation is not aimed at protecting liberal democratic principles, values or institutions, but at preventing harm to others. ${ }^{68}$ Hence, both anti-terror and anti-racist laws can be purely procedural if their scope is defined narrowly in connection to imminent physical harm.

In this light, the demand of punishing the political or terrorist nature behind Golden Dawn's criminal activity was to some extent met by a new 'anti-racist law' (whose introduction was particularly cumbersome and lasted from 2011 until 2014). Law 4285/2014 made a punishable offence of the public and intentional incitement to racist discrimination, hate or violence (Article 1), and of the public and intentional praise, belittlement or denial of genocides, war crimes and crimes against humanity (Article 2). It also increased penalties and fines for Criminal Code violations that were motivated by racist hatred (Article 10), foresaw administrative penalties for legal entities linked to racist crimes and authorised ex officio prosecution for racist crimes. ${ }^{69}$ The law was criticised by the left opposition party SYRIZA

\footnotetext{
${ }^{68}$ I am grateful to Angela Bourne for pushing me to clarify these distinctions.

${ }^{69}$ Law 4285, Government Gazette of the Greek Republic, issue 191, 10 September 2014, p. 6441-6444.
} 
because it restricted free speech rather than criminalising racist violence per $s e{ }^{70}$ As a result, this law fell somewhere between a procedural democratic defence (inasmuch as it targeted racist crimes), and militant democracy (since it restricted ideological speech that was not directly associated with direct harm against others).

In more general terms, however, the procedural model of democratic defence was consistently applied in the case of Golden Dawn, since all measures were justified in connection to its pending criminal prosecution. Take, for example, the decision to suspend its party funding. ${ }^{71}$ It was based on a new law (Law 4203/ 2013, introduced 17 October 2013), which allowed suspension of state funding for political parties, a fifth of whose leadership is under prosecution or remand for organised crime or terrorist acts. Suspension was to take place after an absolute majority vote in Parliament. The new law was defended as 'a basic protection measure for the country and democracy' aiming to prevent 'the possibility of direct or indirect abuse of state funding' to support criminal activities. ${ }^{72}$ Parties were defined as 'actors through whom parliamentary democracy is realized', in other words as state rather than (or in addition to) grassroots agents, which had been the rationale used to justify making parties eligible for state funding in the first place. Some criticised the withdrawal of state funding from parties as a militant measure since it aimed to protect a certain conception of party democracy. ${ }^{73}$ But a closer reading highlights criminal action and not antidemocratic ideas as the prime justification for such a withdrawal. Since it aimed to prevent support for criminal activities rather than defending democratic principles, this type of party funding suspension should be classified as procedural.

Likewise, initiatives of other state institutions followed the same procedural logic. The Greek police often restricted public events organised by Golden Dawn, usually on the grounds of protecting public order (not democracy as such) amid fears of violence due to counterdemonstrations. ${ }^{74}$ Even more pointed was the stance of the Greek Council for Radio and Television (NCRTV). This emerged when the public broadcasting channel ERT refused to air hate speech

\footnotetext{
${ }^{70}$ These fears were realised a year later when, instead of the prosecution of Golden Dawn acts, the law led to the prosecution of a German historian for the way he represented the events of World War

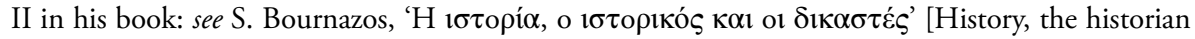
and the judges], 35 Mnemon (2016) p. 358.

${ }^{71}$ It was decided by parliament on 19 December 2013 and (following Golden Dawn's appeal) was confirmed by the Council of State on 16 February 2015.

${ }^{72}$ Ministry of Interior, Amendment for the suspension of state funding for parties, Press Release 30 September 2013, 〈www.e-forosimv.gr/details.asp?ID=20550\&cat=63〉, visited 8 June 2021.

${ }^{73}$ Takis, supra n. 22.

${ }^{74}$ Yet, in reality, and based on ample evidence, the role of the Greek police is more commonly seen as one of collusion and indirect support for ultra-right activity and sentiments, rather than a pillar of anti-fascist combat: see Ellinas, supra n. 5, p. 145-146, 149; Fekete, supra n. 49, p. 53, 56, 63-64.
} 
by Golden Dawn MPs ${ }^{75}$ but was penalised for violating the principle of proportional airtime. ${ }^{76}$ In response, the Council commanded (20 December 2016) ERT to air Golden Dawn's parliamentary speeches, but in other instances (e.g. extraparliamentary events) to evaluate content and decide on broadcasting it on an ad hoc basis, in order to avoid airing speech and actions that support criminal actions. ${ }^{77}$ In other words, airtime and free speech restrictions remained bound to the procedural prevention of regular crime, not to the protection of substantive democratic principles.

While state authorities were consistent in applying a procedural logic, local authorities and civil society have been often more tuned towards a militant democratic paradigm. For example, municipal councils and mayors across the country frequently denied Golden Dawn access to public spaces for their meetings or events, ${ }^{78}$ justifying their decisions as a defence of democratic values (such as human dignity). Similarly, the professional association of broadcasting employees decided on brief strikes every time ERT had to broadcast Golden Dawn's parliamentary speeches, thereby essentially blocking them. Their plan was explicitly aimed at protecting democracy against its enemies. ${ }^{79}$

Last but not least, to procedurally defend democracy involves protecting the functioning of central decision-making institutions from (any type of) undue influence and obstruction. This is why parliaments have in place rules of procedure, ${ }^{80}$ which in the case of Greece were employed to prevent Golden Dawn from inhibiting parliamentary activity. Golden Dawn MPs' parliamentary immunity was repeatedly lifted. ${ }^{81}$ On several occasions, the Speaker imposed disciplinary

${ }^{75}$ Hellenic Broadcasting Corporation (ERT), Announcement for airing activities of Golden Dawn 23.11.2016, Press Release, 28 November 2016, 〈https://press.ert.gr/deltia-typou/ertanakoinosi-gia-provoli-draseon-chrysis-aygis-23-11-2016/>, visited 8 June 2021.

${ }^{76}$ NCRTV (The National Council for Radio and Television), Decisions 290 and 299/ 17.9.2015. For the percentage of airtime per party in various TV channels, see the 2017 report of the National Council for Radio and Television/www.esr.gr/wp-content/uploads/EPOL2017. pdf), visited 8 June 2021.

${ }^{77}$ NCRT, Airing of Golden Dawn on a case-by-case basis, Naftemporiki, 21 December 2016, 〈www. naftemporiki.gr/story/1186106/esr-proboli-tis-xrusis-augis-kata-periptosi $\rangle$, visited 8 June 2021.

${ }^{78}$ Ellinas, supra n. 5, p. 152-153.

${ }^{79}$ For the trade union's announcement of their strike plan against airing Golden Dawn, see /www. pospert.gr/el/anakoinoseis/652-2017-02-24-11-15-34.html), visited 8 June 2021.

${ }^{80} \mathrm{~K}$. Palonen, Parliamentary Thinking: Procedure, Rhetoric and Time (Palgrave 2018) p. 52-56.

${ }^{81}$ The reasons for doing so included: overruling authority and damaging third party property (18 October 2012), carrying illegal weapons (4 June 2014), group robbery (22 October 2014), illegal videotaping (10 December 2014), inciting to violence (13 February 2015), hate speech (12 May 2015), racist law offences (10 February 2016), public service disruption and illegal violence (25 January 2017), ID card falsification (4 October 2017), embezzlement (30 January 2019) and disregard for authorities (20 February 2019). 
measures on the basis of the Parliament's Code of Conduct. Some of them involved individual MPs, whose votes were annulled or who were temporarily expelled, and part of their stipend withheld, or who received a parliamentary fine for acting inappropriately inside the parliament. ${ }^{82}$ In other cases, the entire party was excluded from formal talks or parliamentary votes after provocative incidents, which on one occasion also caused prosecution for high treason. ${ }^{83}$ These initiatives were the result of enforcing the procedural value of non-violent dissensus that has animated parliamentarism as an institution since its inception. ${ }^{84}$

To conclude, the invocation of pending criminal investigations for grave crimes rather than substantive principles to protect democracy is what distinguishes these typically procedural measures from measures adopted in militant democracies.

\section{After the verdict}

After the verdict in October 2020,39 of the convicted persons went to jail and 18 more were placed on remand, while the victims have appealed for stricter sentences. One of the convicted leaders and party cadres, Christos Pappas is still on the run, while another, Ioannis Lagos, an elected MEP had his immunity lifted by the European Parliament and was subsequently arrested on 27 April 2021. ${ }^{85}$ Part of the reason for the delay in Brussels was that the writing of the Athens judgment has not, as of 5 May 2021, yet been finalised, which is also why this article does not contain an analysis of the decision.

The more crucial issue post-trial, however, regards the political rights of jailed MPs and the fact that they, in theory, can continue to be elected from within their prison cells. This was a problem even earlier: during the entire period of the trial, when Golden Dawn MPs were under trail for grave criminal offences and in remand for reasons of public safety, their parliamentary presence remained entirely unaffected. But while the presumption of their innocence explained why the party retained its elected seats until 2019 (when it failed to reach the

\footnotetext{
${ }^{82}$ For example, Kasidiaris (and Sachinidis) received a parliamentary fine and the party was excluded from formal talks after a provocative incident inside the parliament (15 May 2017).

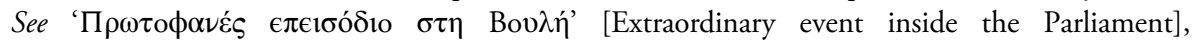
Vouliwatch, 15 May 2017, 〈http://vouliwatch.gr/news/article/protofanes-epeisodio-stin-voyli-okasidiaris-heirodikise-pros-ton-dendia-kai-apovlithike-apo-tin-aithoysa $\rangle$, visited 8 June 2021.

${ }^{83}$ Criminal charges for high treason to Konstantinos Barbarousis, CNN, 15 June 2018, (www. cnn.gr/ellada/story/134602/poiniki-dioxi-gia-esxati-prodosia-ston-konstantino-mparmparoysi $\rangle$, visited 8 June 2021.

${ }^{84}$ Palonen, supra n. 80, p. 47, 80-81.

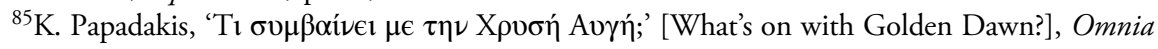
TV, 5 February 2021.
} 
electoral threshold), this reason vanished after their conviction. The problem now is that there is no law that ties this conviction in with the status of their political rights. Because of the strict penal character of the trial and its separation from constitutional or electoral law, translating the criminal conviction of leaders and members of Golden Dawn into a dissolution of the party and its branch organisations has turned out to be a legal puzzle. Likewise, using the verdict to prevent Golden Dawn from reorganising and contesting elections anew remains an open issue that calls for creative solutions.

The main avenue for resolving this conundrum would be a law that temporarily removed the political rights of convicted MPs. Indeed, until 2019, the Criminal Code (Articles 59-61) stipulated the loss of political rights for up to ten years as a result of an irrevocable conviction. Yet, the new law, in force since 1 July 2019 allows only for a 'loss of public positions' and only if the committed crime led to 'a serious breach of duty' (Article 60). ${ }^{86}$ Hence, the new law does not foresee a loss of political rights in connection to off-duty criminal activity. ${ }^{87}$ Even the old law, however, could not preclude the rebirth of the party under a different name that could file new candidates ('Ethniki Avgi' had already been formally established in 2015). In addition, even the old law did not permit the suspension of political rights while the defendants were under trial, or after having received a first-level conviction.

Therefore, immediately after the trial's conclusion, many activists and politicians by all major parties stood in favour of introducing a new electoral law that would regulate the status of political rights of persons convicted in connection with the law on criminal organisations. ${ }^{88}$ More specifically, SYRIZA (left) called for an automatic loss of active and passive electoral rights for life, KKE (far left) for an automatic loss of elected positions and political rights even after a first-level conviction, and KINAL (centre) only for non-eligibility to stand for elections. The governing New Democracy (right) announced plans to amend the election law accordingly, but highlighted that, to be in line with the Constitution, a loss

${ }^{86}$ The 2019 law: 〈www.lawspot.gr/nomikes-plirofories/nomothesia/poinikos-kodikas-nomos4619-2019 >; the old law: 〈www.legal-tools.org/doc/60f2e6/pdf/ , both visited 8 June 2021.

${ }^{87}$ Many conservative politicians attacked the former left-wing government for deliberately having changed the law to protect Golden Dawn. These accusations quickly foundered, when it emerged that the legal reform had been designed since 2012 by non-partisan experts tasked with modernising the penal code.

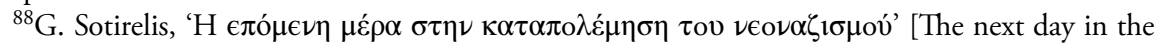

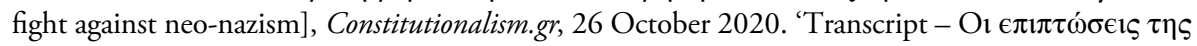

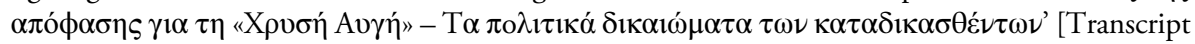
- The consequences of the decision on 'Golden Dawn' - the political rights of the convicts], Kyklos

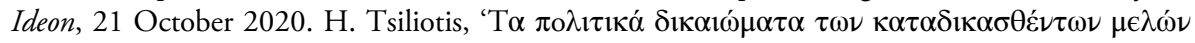
$\tau \eta \varsigma$ XA, $\tau$ o $\Sigma v ́ \nu \tau \alpha \gamma \mu \alpha \kappa \alpha 1 \eta \mathrm{E} \Sigma \Delta \mathrm{A}$ (II)' [The political rights of the Golden Dawn convicts, the Constitution and the ECHR (II)], SyntagmaWatch.org, 24 October 2020. 
can only occur after an irrevocable conviction, that is, at the final level of appellate jurisdiction. ${ }^{89}$ In practice, this means that it may be impossible to legally block the imprisoned MPs from participating in the forthcoming elections (in 2023) due to the long duration of the appeal process. It is outside the scope of this article to discuss the legal details of this ongoing debate. The main point is that a key problem of curbing an antidemocratic party through a criminal prosecution of its leaders is that, even after a positive verdict, their legal right to contest elections and seek power may remain unaffected unless a relevant electoral or party law is in place.

In any case, it is the final phrasing of such law that will determine its consistency with the procedural model. If the intended exclusion from elections is strictly linked to a criminal conviction under regular law (and a very specific, grave and irrevocable one for that matter) and not to conformity with democratic principles, this law can be said to be in line with the central logic of the procedural model of democratic defence. If, instead, the exclusion is connected with political parties' constitutional obligation to 'serve the free functioning of the democratic form of government' (Article 29.1), we are sliding into militant-democratic terrain. In addition, framing the exclusion in terms of admissibility for election instead of a permanent loss of political rights is much more welcome from a procedural perspective to democracy as a regime founded on political pluralism.

\section{Conclusions}

The conviction of Golden Dawn in 2020 as a criminal organisation highlighted that the main mechanism used by the Greek state against the neo-Nazi party was the mobilisation of criminal law. This supports the claim that Greece is not a militant democracy. By applying the two models - militant and procedural democratic defence - to a specific case, this paper has highlighted that their main difference is not a militant willingness to impose restrictions on a party versus a procedural refusal to do so. Instead, what emerged as the key divide is the normative principle behind restrictions and the type of restrictions it justifies. While militant democracies enforce exceptional civil rights restrictions on the basis of substantively conceived (and often vaguely defined) democracy-protecting values, procedural democracies only mobilise regular law against the threat or evidence of direct physical harm perpetrated by individuals associated with the party. The logic behind these two approaches is fundamentally different, as the former relies on a value-based protection of the form of government, whereas the latter remains agnostic as to the political and ideological motives of criminal actions. This logic

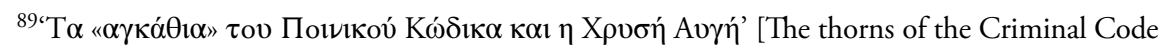
and Golden Dawn], Kathimerini, 9 October 2020. 
separates the two models, regardless of whether it is embedded in constitutional or other types of law.

Despite the commitment of the Greek state and society to a procedural approach, the fight against Europe's most extreme far-right party produced some tendencies in favour of militant democracy. They included attempts at reading 'militancy' into the Greek constitution, constitutional reform proposals, appeals to anti-dictatorship laws, the government appearing to bring the party to court and a widespread use of militant language by civil society actors. These developments underline the contingent nature of how a democracy can become militant, that is, how attractive this option can become in critical times and the fact that legal traditions are subject to change given a sufficient amount of external pressure. Yet, in essence, and due to specific historical and politico-cultural circumstances, Greece is not a militant but what I have called a procedural democracy. Political parties and participation rights are in principle constitutionally protected. This method may be more protective of free speech, free association and political pluralism compared to constitutional party bans. But this model has its own limitations.

From the response to Golden Dawn, three lessons can be learned about how a procedural democracy can perform better under stress. First, a procedural model requires a strong and independent judiciary that enjoys social legitimacy. Second, a procedural model needs to have in place criminal legislation and a system of monitoring not only commitment but also incitement to acts of politically motivated violence, so that one need not wait for grave crimes to occur in order to initiate an indictment process. Third, it is important to have in place parliamentary procedures that protect the legislative process from various types of unparliamentary behaviour.

Granted, the procedural model may be a high-risk one for defending democracies from far-right parties. As the Greek case has shown, not only can the criminal prosecution take too long to start - or indeed to end - but it may also be ineffective or slow in removing far-right parties from the political scene. On the other hand, the procedural model is also high-gain. It has the ability to defend democratic governments and citizens, without employing exemptions on fundamental political rights, undermining the integrity of the democratic system or challenging principled commitments to democratic pluralism. The suitability of this model for a specific institutional context should, therefore, be judged by weighing its high risks against its high gains. 